\title{
Build Customer Loyalty with CRM and Brand Image (Case Study on Giant Citra Raya)
}

\author{
Dr. Antonius Setyadi ${ }^{1)}$, \& Prof. Dr. Hapzi Ali ${ }^{2)}$ \\ ${ }^{1)}$ Lecturer of Graduate Mercu Buana University, Jakarta Indonesia \\ ${ }^{2)}$ Professor of Graduate Mercu Buana University, Jakarta Indonesia
}

\begin{abstract}
Giant Customer Citra Raya Tangerang over the last five years (2011-2015), had a significant decrease. The decrease is due to customers by many factors including the quality of kerelasian with customers $(C R M)$ is not good and the products or services on offer does not corresponds to the expectations of customers, so the Brand Image decreased. The sampling method non-probability sampling (samples are not random). The sampling technique accidental sampling (how unintentional), where researchers have the freedom to choose who sampled according to the requirements of the existing population. The research method is a survey method. Customers population average of 2,070,823 / 12/30 = 5752 per day, with a sample of 152 respondents Slovin method. Method of quantitative analysis by means of multiple linear regression analysis followed by analysis test of determination ( $R$ Square), testing the hypothesis partially ( $t$ test) and simultaneous (test $F)$ the error tolerance level of 5 percent. The results of the research that CRM and Brand Image positive and significant impact on the Customer Loyalty, either partially or simultaneously. Cusomer Loyalty can be built with CRM and brand image, the better CRM and Brand Image in perceived by customers the more loyal customers at Giant Citra Raya. CRM and Brand Image can explain Customer Loyalty at 71.8 percent was 28.1 percent in perngaruhi sebsar other variables.
\end{abstract}

Keywords: CRM, Brand Image, Customer Loyalty, Giant Citra Raya.

\section{Introduction}

The business environment is rapidly changing. As well as the retail sector business competition forced retailers continue to innovate and imitate each other in seizing the customer to win the competition. With the strategy of mimicking each other to make each retail concept similar difficult to distinguish anymore.High competition retail business led to customers facing more alternative products, prices and quality vary, so customers are always looking for products that are of high value, excellent products, management of customer relationships or Customer Relationship Management (CRM), brand image, quality of service and other factors, Kerelasina low service quality will lead to customer dissatisfaction, as well as the retail business. If the customer is disappointed to be told at least to the 15 others, and this will have an impact on brand image. Another effect is that the prospect will impose his choice to competitors (Lupiyoadi and Hamdani, 2006). Efforts to improve the quality of service or the management system kerelasian palnggan, will be much more effective for the sustainability of business activities.

Generally it is said that if customers are satisfied with the products or services offered, they then may re-purchase and add to their purchase (Kotler, 2008). A satisfied customer may tell the others about their mutual experiences, thus generating the information by word of mouth is positive, thereby increasing the company's market share. (Ozkaya and Selda E 2014).Table 1 below can be analyzed that the visitors Giant Citra Raya in the last five years showed a decline, so management is trying to find the cause of the decrease in the number of customers whether internal factors or external factors. The data on the number of customer Giant Citra Raya last five years are as follows:

Table 1: Visitors Giant Citra Raya Year 2011-2015

\begin{tabular}{|l|l|l|l|l|}
\hline No & Year & Actual & Last Year & \% vs Last Year \\
\hline 1 & 2011 & 3.139 .818 & & \\
\hline 2 & 2012 & 2.186 .688 & 3.139 .818 & $-30 \%$ \\
\hline 3 & 2013 & 2.108 .299 & 2.186 .688 & $-4 \%$ \\
\hline 4 & 2014 & 2.073 .589 & 2.108 .299 & $-2 \%$ \\
\hline 5 & 2015 & 2.070 .823 & 2.073 .589 & $-1 \%$ \\
\hline
\end{tabular}

Source: Giant Citra Raya (2015)

Over five years ago Giant Citra Raya received several complaints submitted to the company's customers, as for the complaint data on the Inventory are as follows:

1) Service Unit: (1) lack of personnel, so that when customers need information officer must seek advance; (2)

The cashier provided insufficient, so that the customer should have to queue at the time to pay; and (3) less friendly cashier. 
2) Section Product: (1) Certain products are often out of stock so that customers who specifically want to buy these products to feel disappointed; (2) The lack of variety of products, so customers difficult to compare; The products are sold fresh sometimes even less fresh it is not feasible.

Improvements to the quality customer relationships (CRM) and efforts to build a good brand image is an umbrella decisive in following up on consumer complaints of a failure that ultimately capable of satisfying consumers and consumers into customers and ultimately become customers loyal to the company. Consumer satisfaction of quality management of customer relationships and brand image is not only valuable in good economic times, but also in less stable economic times still have strived to constantly improve the quality of customer relations and brand image. Based on the background of the problem, the purpose of this study was to investigate and analyze:

1) Effect of CRM to Customer Loyalty, partially, in the Giant Citra Raya;

2) Effect of Brand Image to Customer Loyalty, partially, in the Giant Citra Raya; and

3) Effect of CRM and Brand Image to Customer Loyalty, simultaneously, the Giant Citra Raya.

\section{Literature Review And Hypothesis \\ Customer Loyalty}

Loyalitasatau banking customer loyalty (customer loyalty) is defined as a person's loyalty to an object or body. Mowen and Minor (2005: 42) defines loyalty as a condition where the customer has a positive attitude toward a brand tau lemabga, a commitment to the brand or the institutions, and intends to continue the purchase in the future. Customer loyalty shown a tendency to use a particular brand with a high level of consistency (Dharmmesta, 2006: 53 in Murdalis, 2005: 24).

Kotler, Hayes and Bloom (2002: 153) mentions six reasons why an institution needs to gain the loyalty pelanggan.Pertama: there are more prospective customers, means that loyal customers will provide great benefits to the institution. Second: the cost to acquire a new customer is much larger when compared to keep and retain existing customers. Third: customers who already believe in the institution in an affair will believe also in other matters. Fourth: operating costs more efficiently if it has a lot of loyal customers. Fifth: the institution may deduct the psychological and social costs due to old customers have had many positive experiences with the institution. Sixth: loyal customers will always defend the institution even trying also to attract and give advice to others to become customers.Kotler and Keller (2009: 140) states loyalty is built with three elements, namely repetation), retention, and referall, or re transactions, loyal to the institution and the recommendation to other customers.

\section{Stages Characteristics and Customer Loyalty}

Customers demonstrate their loyalty to a company or brand to buy repeatedly, purchase additional products such companies, and recommend it to others. This is reinforced by statements from Griffin (2005: 31), which states that the characteristics of loyal customers include:

a. Make repeat purchases regularly.

b. Antarlini buy products and services.

c. Showed resistance to the pull of competitors

d. Refer to others.

To become a loyal customer a consumer must go through several stages, loyal customers is growing gradually. The process was passed in a given time period, with compassion, and with attention given to each stage of growth. Each stage has its specific needs. By recognizing each stage and meet the specific needs, companies have greater opportunities to turn shoppers into loyal customers or clients.

According to Griffin (2005: 35), there are 8 stages loyalty, namely:

a. Suspect: People who might buy your products or services. In this case we believe it or "think" they will buy but we are still not quite sure.

b. Prospects: People who need your products or services and have the ability to buy. Although prospects have not purchased from you, he might have heard of you, reading about you, or someone recommended you to him.

c. Prospects The Disqualification: Prospects who have learned enough to know that they do not need, or do not have the ability to buy, your product.

d. First-time customers: People who have bought from you once. That person could be your customers and your competitors as well as customers.

e. Repeat Customers: People who have bought from you twice or more. They may have bought the same product twice or buy two different products or services on two or more occasions.

f. Client: This man bought a regular basis. You have a strong and continuing relationship, which makes it immune to the pull of competitors. 
g. Advocate (Advocate): As a client, supporter buy whatever you're selling and can he used as well as buy them regularly. However, the advocate also encourage others to buy from you. He was talking about you, do the marketing for you, and bring customers to you.

h. Customer or Client Lost: Someone who never become customers or clients but do not buy back from you at least in the normal buying cycle.3) Brand Image.

\section{Customer Relationship Management}

Customer Relationship Management (CRM) is an integrated information system that is used to plan, schedule and control the presales activities and postsales within an organization. CRM embraces all aspects of dealing with prospects and customers today, including the call center (call center), sales force (sales force), marketing, technical support (technical support) and field service (field service), Anonymous Wikepedia (2017). The ultimate goal of CRM is to improve long-term growth and profitability through a better understanding of the habits (behavior) customers. CRM aims to provide more effective feedback and improved integration to better gauge the return on investment (ROI) in these areas.

Sales Force Automation (Sales force automation / SFA), which became available in the mid-80s is the first component of CRM. SFA helps sales representative to set up accounts and track opportunities to them, set the list of contacts they have, arrange their work schedules, providing online training can be a solution for training long-distance, and to build and oversee the flow of their sales, and also help optimize submission of information to the news sharing.SFA, call centers and automated field operations exist in the same lane and entered the market in the late '90s began joining into the CRM market. Just as ERP: Enterprise Resource Planning), CRM is a very comprehensive system with a lot of packages and options.

Referring to Glen Petersen, author of "ROI: Building the CRM Business Case," the most successful CRM systems found in organizations that adjusts its business model to profitability, not just redesign their information systems.CRM includes the methods and technologies used by companies to manage their relationships with customers. The information stored for each customer and potential customer is analyzed and used for this purpose. Process automation in CRM is used to automatically generate personalized marketing based on customer information stored in the system. CRM in this context is the quality of management or the quality of Reviews their CRM Customer relationships are methods for maintaining customer satisfaction to enable the sustainable customer relationships. Kenna (1991: 132) in Hapzi Ali (2012) revealed the presence of the five principles in implementing customer relationship marketing are:

- Placing the market as the center of the marketing organization.

- Marketing is the creation of a market (market creation) rather than market share.

- Marketing is a matter of process and not a promotional tactic.

- Marketing is qualitative and not quantitative.

- Marketing is a task or job everyone.

CRM has two elements (dimensions) is important, namely trust and commitment. Kerelasian customers will `confidence (trust) and commitment customers, so that eventually the company's image will be awakened. The image is a whole of a person's perception is one thing that is formed through a process of information obtained from various sources.Banwari Mittal (2001:21) says that the main core of the relationship is trust. Some other opinions that say that "commitment" and "trust", is the central role of relationship marketing forward by (Boyle et.al, 1992: 8; Crosby, Evans and Cowles, 1997:78), Palmer Andrian (2001:35); in Hapzi Ali (2012).

\section{Brand Image}

There are several different definitions or views on brand image, where the differences in this view rely on extensive image is built in the minds of consumers. Here are a couple of terms of brand image from several sources:

a. Brand image is a set of consumer confidence about the particular brand (Kotler and Armstrong, 2001: 225).

b. Brand image is a collection of perceptions about a brand interrelated that exist in the human mind (Ouwersoot and Tudorica, 2001)

c. "Brand image can be defined as a perception about a brand as reflected by the brand association held in consumer memory". This means that the brand image is the perception of the brand represented by brand associations in consumer memory (Keller, 1998: 93).

d. "Brand association is anything linked in memory to a brand". This understanding shows that brand association is something that relates to the brand in the minds of consumers (Aaker, 1991: 109).

Both Keller and Aaker suggests that the close relationship between brand association with the brand image in which the association that exists to a brand can establish brand image. Brand association can assist in the recall of information relating to products, especially during the manufacturing process to make a purchase decision. So, between the brand image and brand association has a close link integral with each other. 
Brand Image in the context of this Brand Image quality: According to Flavian, Torres, and Guinaliu (2004; 384) in Hapzi Ali (2010: 60), that the measurement of brand image generated by the four elements (dimensions) that can cirtra form of banking items, namely access to services, service offered, personal contact, security and reputation, the which will be used in this study.Access to services consists of indicators ease in using the service, timeliness of transactions, convenient service, the operational schedule of the bank, and the possibility to file a complaint / protest. Services offered (service offered) consists of indicators of the availability of the number of products and services, the appeal of the products and services offered, the interest of both savings products, loan interest payments, and the payment of fees. Personal relationship consists of indicators employees, individual attention, personal contacts, financial advisory services, ease of consultation. Security consists of the security indicator in the transaction, security in saving money, security data. Reputation) of the company consists of banking pledge of confidence indicators, the reputation of the services offered, confidence in the banks that have exceeded other institutions. (Flavian, Torres, and Guinaliu, 2004: 384).

\section{Factors shaping the brand image}

According to Keller (1993: 3) factors that form the image of the brand are:

a. Brand association strength (strength of brand association). Depending on how information is entered into the consumer memory and how it is to survive as part of the brand image

b. Advantage brand association (favourability of brand association). The success of a marketing process often depends on the process of creating a favorable brand association, where consumers can trust in a given attribute they can satisfy the needs and desires of consumers.

c. The uniqueness of brand associations (Uniqueness Of brand association). A brand must have a competitive advantage that is the reason for the consumer to choose a particular brand. The uniqueness of brand associations dpat based on product attributes, product functionality or image enjoyed by consumers.

\section{Conceptual Framework}

Framework brfungsi to design influences or relationships between variables. CRM variables that affect the Customer Loyalty partially based on research Krisna, Hapzi Ali (2010: 8). Brand Image effect on Customer Loyalty partially based on research Ehigie (2006), CRM and Brand Image effect on customer loyalty based on research Kursunluoglu (2007). CRM positive and significant impact on the Customer Loyalty partially: Gane et al (2013), Hapzi, Varuna, and Chree (2012), and Hafez and Muhammad. CRM, service quality and brand image and significant positive effect on customer loyalty either partially nor Mr simultaneously: Stan, Caemmerer, Jallet (2013), Ndubisi, Wah (2007), and Hapzi, Varuna, and Chree (2012).That Kereleasian Customers (CRM) positive and significant impact on the brand image or the Institution, either partially or secaras imultan, the banking customers in Jambi, Hapzi Ali \& Adji Djoyo, (2012). Brand Image and CRM Quality also positive and significant impact on both customer satisfaction and simultaneously secaraparsial and impact on customer loyalty, Hapzi Ali, Nandan Limakrisna, et al, (2016). Based on the purpose of research, literature reviews, previous studies and research rood folder, then the framework of this study is as Figure 1 below.

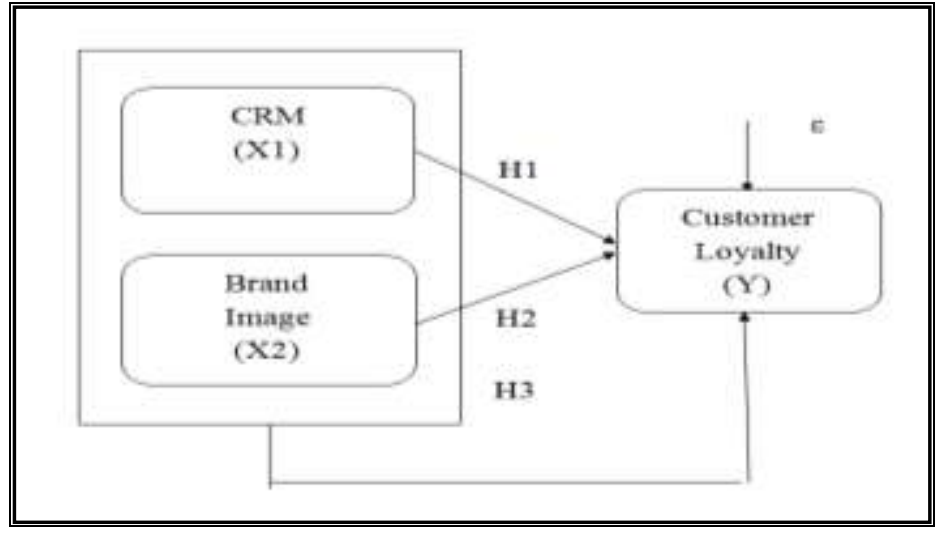

Figure 1: Conceptual Framework

Based on the objective of the research, the study of theory and previous research as well as the road map for researchers, the research hypothesis is:

1) CRM positive effect on the Customer Loyalty, partially, in the Giant Citra Raya .;

2) Brand Image positive effect on the Customer Loyalty, partially, in the Giant Citra Raya .; and

3) CRM and Brand Image positive effect on the Customer Loyalty, simultaneously, the Giant Citra Raya. 


\section{Methods}

Design research is explanatory. The sampling method used is a non-probability sample or not random. The sampling technique in this research is using accidental sampling (how unintentional) where researchers have the freedom to choose who encountered which can be sampled as per the requirements of the existing population. The method used in this study is a survey method. The population in this study is that consumers or customers Giant Citra Raya. Average visitors or customers 2,070,823 / 12/30 $=5,752$ per day. The samples used a proper sampling method in order to obtain a representative sample and to describe the state of the population to the fullest. Therefore, the sample collection technique is done with accidental sampling to determine customers who become members of the sample. The size or the number of samples in this study are determined based on the theory developed by Slovin, Umar (2008: 141) with a sample of 152 respondents. The analysis tool is the multiple linear regression equation $\mathrm{Y}=\beta 0+\beta 2 \mathrm{X}_{2} \beta 1 \mathrm{X}_{1}++\mathrm{e}$, where $\mathrm{Y}$ is the variable Customer Loyalty, $\beta 0$ constant coefficient regression, $\beta 1$ coefficient CRM $\left(\mathrm{X}_{1}\right), \beta 2$ coefficient Brand Image $\left(\mathrm{X}_{2}\right)$. SPSS analysis tools under windows version 20:00.

Before the multiple linear regression analysis with first tested the questionnaire instrument to test the validity and reliability as well as classical assumptions of indicators, dimensions and variables of the study. Analysis of determination (R Square) was conducted to see how much the independent variables are able to explain or can form a dependent variable. Testing the hypothesis partially ( $t$ test) and simultaneous (test $F$ ) the error tolerance level of 5 percent. The results of the research that CRM and Brand Image positive and significant impact on the Customer Loyalty, either partially or simultaneously.

\section{Multiple linear regression analysis}

\section{Result \& Discussion}

The results of the study as table 2 below. The results show multiple linear regression equation: $=0685$ $+0,072 \cdot X_{1}+0,522 \cdot X_{2}+$ e. Description: Koeefeisien Konstantan $=0685, Y$ variable Customer Loyalty $(Y), \beta 1$ koefeisien CRM $\left(\mathrm{X}_{1}\right)=0.072$ and $\beta 2$ Brand Image $\left(\mathrm{X}_{2}\right)=0,522$

Tabel 2.

\begin{tabular}{|c|c|c|c|c|c|c|}
\hline \multicolumn{7}{|c|}{ Coefficients $^{\mathrm{a}}$} \\
\hline \multirow{2}{*}{\multicolumn{2}{|c|}{ Model }} & \multicolumn{2}{|c|}{$\begin{array}{l}\text { Unstandardized } \\
\text { Coefficients }\end{array}$} & $\begin{array}{l}\text { Standardized } \\
\text { Coefficients }\end{array}$ & \multirow[t]{2}{*}{$\mathrm{t}$} & \multirow[t]{2}{*}{ Sig. } \\
\hline & & $\mathrm{B}$ & Std. Error & Beta & & \\
\hline \multirow[t]{3}{*}{1} & (Constant) & .685 & .595 & & 1.15 & .252 \\
\hline & CRM_X1 & .072 & .013 & .419 & 5.59 & .000 \\
\hline & Brand_Image_X2 & .522 & .083 & .471 & 6.29 & .000 \\
\hline
\end{tabular}

Source: Output SPSS 20.0 for windows

From the equation above can be interpreted:

1) Variable CRM and Brand Image has berkoefisien positively to Customer Loyalty;

2) Constant value of 0685. Menejelaskan that if the independent variable is CRM and Brand Image is not implemented, then the dependent variable is Customer Loyalty fixed at 3.032 (303.2 percent);

3) CRMmemberikan variable coefficient value of 0.086 which means that if a company has a good CRMyang it will be able to increase Customer Loyaltysebesar 8.6 percent, assuming other variables remain;

4) Brand Imagememberikan variable coefficient value of 0.153 if the company is able to provide a good brand image then able to increase customer loyalty by 15.3 percent, assuming other variables.

\section{Determination analysis $\left(\mathbf{R}^{2}\right)$}

The $\mathrm{R}$ value of 0.847 in Table 3 below shows the correlation double (CRM and Brand Image) with Customer Loyalty. Taking into account the variations in the value of $\mathrm{R}$ Square of 0.718 which indicates the magnitude of the role or contribution of CRM and Brand Image afford or can explain the variable customer loyalty at 71.8 percent and the remaining 28.2 percent is influenced by other variables.

Table 3.

\begin{tabular}{|l|l|l|l|l|}
\hline \multicolumn{4}{|l|}{ Model Summary } \\
\hline Model & $\mathrm{R}$ & R Square & $\begin{array}{l}\text { Adjusted R } \\
\text { Square }\end{array}$ & $\begin{array}{l}\text { Std. Error of } \\
\text { the Estimate }\end{array}$ \\
\hline 1 & $.847^{\mathrm{a}}$ & .718 & .714 & .85947 \\
\hline \multicolumn{5}{|l|}{ a. Predictors: (Constant), Brand_Image_X2, CRM_X1 } \\
\hline
\end{tabular}

Source: Output SPSS 20.0 for windows

Other variables that may affect customer loyalty include product quality, customer satisfaction, price, promotion and so forth. 


\section{Effect of Partial (t test) and Simultaneous Effect (Test F)}

Assessment of the effect of partial aims to examine whether each of the independent variables significantly influence the dependent variable partially with $=0.05$ and also the acceptance or rejection of the hypothesis. Partial test ( $t$ test) to answer a hypothetical one and two of this study.

Table 4. Hasil Uji t (Parsial)

\begin{tabular}{|l|l|l|l|}
\hline No. & Independent Variable & t Value & Sig. \\
\hline 1 & CRM $\left(\mathrm{X}_{1}\right)$ & 5.597 & 0.000 \\
\hline 2 & Brand Image $\left(\mathrm{X}_{2}\right)$ & 6.299 & 0.000 \\
\hline
\end{tabular}

Source: Output SPSS 20.0 for windows

From Table 4 above with figures obtained t count $\mathrm{X} 1$ variable of 5.597, because $\mathrm{t}$ count> $\mathrm{t}$ table (65.597> 1,683), then Ho is rejected and $\mathrm{H} 1$ accepted, meaning partially significant effect on the CRM Customer Loyalty. In addition, also for the test based on significance testing, can be seen from the output of significance of 0.000 , due to number more significance level of $<0.05(0.000<0.05)$, it can be concluded that CRM positive and significant impact on customer loyalty, thus the first hypothesis is accepted. Furthermore, in Table 4 above figures obtained $t$ count variable Brand Image (X2) of 6299, due to the value of $t>t$ table $(6,299>$ 1,683), then Ho is rejected, it means there was an effect partially Brand Image on Customer Loyalty. In addition, also for the test based on significance testing, can be seen from the output of significance of 0.000 , due to the significance level figures much of $<0.05(0.000<0.05)$, it can be concluded that Brand Image significant effect on customer loyalty, thus the second hypothesis is accepted.To answer the third hypothesis THAT CRM and Brand Image effect on Customer Loyalty simultaneously can be seen from Table 5 below.

Tabel 5 .

\begin{tabular}{|c|c|c|c|c|c|c|}
\hline \multicolumn{7}{|c|}{ ANOVA $^{\mathrm{a}}$} \\
\hline \multicolumn{2}{|c|}{ Model } & Sum of Squares & $\mathrm{df}$ & Mean Square & F & Sig. \\
\hline \multirow[t]{3}{*}{1} & Regression & 280.251 & 2 & 140.125 & 189.694 & $.000^{\mathrm{b}}$ \\
\hline & Residual & 110.065 & 149 & .739 & & \\
\hline & Total & 390.316 & 151 & & & \\
\hline
\end{tabular}

Source: Output SPSS 20.0 for windows

From Table 5 above (ANOVA table) obtained Fhitung 189.694lebih than Ftabel 3:10 (189 694> 3.10) and a significant value of 0.000 is less than 5 percent $(0.000<0.05)$. Then the null hypothesis $(\mathrm{H} 0)$ is rejected and the alternative hypothesis (H1) is accepted, meaning that there is significant influence variable CRM (X1) and Brand Image (X2) on Customer Loyalty (Y) together (simultaneously) at Giant Citra Raya (PT. Hero Supermarket Tbk) in Tangerang. Thus the third hypothesis is accepted. From these results, the discussion is as follows:

\section{1) CRM effect on Customer Loyalty}

CRM positive and significant impact on the Customer Loyalty, partially on Giant Citra Raya. CRM dimension means trust and commitment Reviewed psoitif and significant influence also on the dimensions of Customer Loyalty is repeated transactions, loyal to the institution and the recommendation to other customers. The results are consistent with previous research that has been done Hapzi \& Adji (2012), Falvian Torres \& Guinaliu (2004), and Malik and Ghafoor (2012), That Custome Relationship Management (CRM) and a significant positive effect on Customer Loyalty.

\section{2) Brand Image effect on Customer Loyalty}

Brand Image positive and significant impact on the Customer Loyalty, partially on Giant Citra Raya. Brand Iamge dimension means that access to services, service offered, personal contact, security and reputation psoitif and significant influence also on the dimensions of the transaction Customer Loyalty ie, loyal to the institution and the recommendation to other customers. The results are consistent and supportive research is conducted Hapzi Ali, Nandan Limakrisna, et al, (2016). Brand Image positive and significant impact on customer satisfaction and impact on Customer Loyalty.

\section{3) CRM dan Brand Image effect on Customer Loyalty}

CRM and Brand Image positive and significant impact on the Customer Loyalty, simultaneously, the Giant Citra Raya. CRM dimension means that trust and commitment and dimensions Brand Iamge is access to services, service offered, personal contact, security and reputation psoitif and significant influence also on the 
dimensions of Customer Loyalty is repeated transactions, loyal to the institution and the recommendation to other customers.

The results are consistent also with the results of the research: 1) Hapzi \& Adji (2012), Falvian Torres \& Guinaliu (2004), and Malik and Ghafoor (2012), That Custome Relationship Management (CRM) and a significant positive effect on the Customer Loyalty; 2) Gane et al (2013), Hapzi, Varuna, and Chree (2012), and Hafez and Muhammad, that CRM and significant positive effect on the Customer Loyalty either partially; 3) Hapzi Ali \& Adji Djoyo (2012). A CRM system should be able to run the function: Identify the factors that are important to customers; Carrying the customer-oriented philosophy (customer centric); Adopt measurement based on the customer's perspective; Build processes end to end in serving customers; Providing perfect customer support; Handle complaints / customer complaints; Record and follow all aspects of the sale; and Creating a holistic information about services and sales information from customers, Anonymous Wikipedia (2017).

\section{Conclusion:}

\section{Conclusion}

1) CRM positive and significant impact on the Customer Loyalty in the Giant Citra Raya. The better the quality of CRM provided to the customers it will have an impact on customer loyalty.

2) Brand Image positive and significant impact on the Customer Loyalty in the Giant Citra Raya. The better the customer's perception of the brand image will have an impact on customer loyalty.

3) CRM and Brand Image positive and significant impact on the Customer Loyalty in the Giant Citra Raya. The better the quality of CRM and brand image that is perceived by the customer it will have an impact on customer loyalty.

\section{Suggestion:}

1) To increase customer loyalty, Giant Citra Raya must pay attention to CRM Quality and Brand Image Quality is best. Make sure the products that customers purchase can be used optimally and give satisfaction to the consumer. Thus, if consumers are satisfied with CRM and gives the impression of a good brand image, it can also build customer loyalty at Giant Citra Raya.

2) There is another factor that affects apart from CRM Customer Loyalty and Brand Image based on the analysis of determination. To ensure that any factor that affects customer loyalty, it is necessary to conduct further research by researchers primarily academic researchers.

3) In the research further, researchers can conduct research with marketing variables other than the variables that have been studied, also with data analysis method to another, so that later obtained the findings of a new and more accurate results that can add to or supplement the results of research which has existed. Finally, hopefully the data and this information can help similar companies in increasing sales.

\section{References}

[1] Ahmed, Zohaib, Muhammad Rizwan, Mukhtar Ahmad. (2014). "Effect of brand trust and customer satisfaction on brand loyalty in Bahawalpur". Journal of Sociological Research. Vol. 5, No.1 pp:306-326.

[2] Aker, David, 1991, Managing Brand Equity; Capitalizing on the Value of Brand Name, Free Press, New York.

[3] Akbar, M, dan Parvez, N. (2009). "Impact of Service Quality, Trust, and Customer Satisfaction on Customer Loyalty". ABAC Journal, Vol 29 (1), pp: 24-38

[4] Ali Hapzi, H., Nandan, N.L., (2013). Research methodology. Issue 1, Cet. 1, Deepublish, Yogyakarta.

[5] Ali Hapzi, Adji Djojo (2012), "Information Technology service performance and client's relationship to increase banking image and its influence on deposits customer banks loyalty (a survey of Banking in Jambi). Journal Archives Des Sciences Switzerland (Geneva), ISSN : 1661464x, International Science Index /ISI-THOMSON Indexed Journal (2010 Impact Factor : 0.474), Page. 538-55.

[6] Ali Hapzi, Nanda Limakrisna, Said Djamalluddin (2016), Model of customer satisfaction : the empirical study at BRI in Jambi. International Journal of Applied Business and Economic Research (IJABER) www.serialsjournal.com, ISSN : 0972-9380, Terindex Scopus 0.100 (Q4), Vol. 13,No. 3, New Delhi India, Page: 707-719

[7] Ali Hapzi \& Henry Mappesona, 2016. Build Brand Image: Analysis . uality and Product Quality (Case Study at Giant Citra Raya). International Economic Research (IJER),ISSN: 0972-9380. www.serialsjournals.com, Indexing: Scopus Q3,0.123. No. 13. Issue No. 5, Page: 2191-2211

[8] Ali Hapzi, Nandan, et. al, 2016. Model of customer satisfaction :the empirical study at BRI in Jambi. International Journal of Applied Business and Economic Research (IJABER), ISSN: 0972-9380. www.serialsjournal.com, Indexing: Scopus, Q4, 0.100. Vol. . 13,No. 3, New Delhi India, Page: 707-719.

[9] American Journal of Industrial and Business Management, Vol. 2, pp: 217-229.

[10] Angelova, Biljana, Jusuf Zekiri. (2011)."Measuring Customer Satisfaction with Service Quality Using American Customer Satisfaction Model (ACSI Model)”. International Journal of Academic in Business and Social Sciences Vol.1,No,3, p232.

[11] Berry, L., Zeithaml, V., Parasuraman, A (2008) The Service-, Quality Puzzle. Business Horizons.

[12] Doll W.J. dan Torkzadeh, G. \& Weidong, Xia. (1994). A Confirmatory Factor Analysis of the End-User Computing Satisfaction Instrument. MIS Quarterly. Vol. 18, No.4, pp:453-461

[13] Doyle, Peter. 1998. Marketing management (4th ed.). New York: Mc Graw Hill

[14] Enel, Selda, Betül Özkaya. (2014). "Customer Satisfaction and Brand Loyalty in the Context of Retail Stores". Asian Social Science by Canadian Center. Vol. 10, No, 14, pp:52-66.

[15] Griffin, Jill. (2005). Customer Loyalty, Cultivating and Maintaining Customer Loyalty. Erlangga. Jakarta. 
[16] Hair, Anderson, dan Thatam Black. (1995). Multivariate Data Analysis with Reading. Prentice Hall, London.

[17] uddleston, Patricia, Judith, Rachel Mattick and So Jung Lee. (2009). "Customer Satisfaction in Food Retailing: Comparing Specialty and conventional Grocery Stores”.International Journal of Retail \& Distribution Management. Vol. 37, No, 1, pp 63-80.

[18] Irawan, Handi. (2009). "10 Prinsip Customer Loyalty". Jakarta : PT. Elex Media Komputindo.

[19] Kheng, Lo Liang, O Mahamad, Ramayah. (2010). "The Impact of Service Quality on Customers Loyalty : A Study of Banks in Penang”. International Journal of Marketing Studies. Vol. 2, No,2, pp:57-66.

[20] Kotler, P., \& Garry Armstrong, (2012). Prinsip-prinsip Pemasaran. Edisi 12, Jilid 2, Erlangga, Jakarta.

[21] Kotler, P., \& Keller, K.L., (2008). Marketing Management (13th edition). Prentice-Hall International, Inc., NJ.

[22] Keller, Kevin Lane. 1998, Strategic Brand Management : Building, Measuring, and Managing Brand Equity, Prentice Hall, New Jersey.

[23] Keller, L. 1993. How to manage brand equity. Jakarta: GRamedia PustakaKotler, Phillip dan Gary Amstrong. 2001. Principles of Marketing, vol 2, 8th edition, publisher, Jakarta.

[24] Krisna, (2010). Service Quality and its Effect on Customer Satisfaction in Retailing. Vol. 16, No,2, pp:231-243.

[25] Kursunluoglu, Emel. (2007). "Customer Service Effects on Customer Satisfaction and Customer Loyalty: A Field Research in Shopping Centers in Izmir City - Turkey”. International Journal of Business and Social Science. Vol.2,No.17, p52.

[26] Lovelock, Christoper, Jochen Wirtz dan Jacky Mussry. (2012). Pemasaran Jasa Manusia, Teknologi, Strategi. Jilid I. Edisi ke tujuh. Erlangga. Jakarta

[27] Lupiyoadi, Hamdani. (2006). "Marketing Management Services, Second Edition Jakarta "Publisher Salemba Four.

[28] Malhotra, Naresh K., dan Birks, David F. (2009). Marketing Research An Applied Approach. Second Edition. Prentice Hall. Harlow.

[29] Munusamy, Jayaraman, Shankar Chelliah, Hor Wai Mun. (2010). "Service Quality Delivery and Its Impact on Customer Satisfaction in the Banking Sector in Malaysia". International Journal of Innovation, Management and Technology. Vol.1,No,4, pp:398-404.

[30] Naik, Krishna, Swapna Bhargavi Gantasala, Gantasala Prabhakar. (2010). "New York Institute of Technology Sixth circle/Service Quality (Servqual) and its Effect on Customer Satisfaction in Retailing”. European Journal of Social Sciences. Vol.16,No,2, pp:231243.

[31] Ouwersloot, Hans and Tudorica Anamaria, 2001, Brand Personality Creation through Advertising” dalam Maxx Working Paper 2001-01, February 2nd 2001

[32] Saif, Ulah Malik. (2012). "Customer Satisfaction, Perceived Service Quality and Mediating Role of Perceived Value". Vol.4, No. 1, pp:68-76.

[33] Taylor, Shirley F, Harvir S Bansal, dan P. Gregory Irving. (2004). "Three Component Model of Customer Commitment to Service Providers". Journal of The Academy Marketing Science. Vol. 32, No. 3, pp: 234-250. 